\title{
On Biometrical Aspects of the Cephalic Anatomy of Xisqueta Sheep (Catalunya, Spain)
}

\author{
Aspectos Biométricos de la Anatomía Cefálica de la Oveja Xisqueta (Cataluña, España)
}

Parés, I. Casanova, P. M.; Sarma Kamal \& J. Jordana

PARÉS I CASANOVA, P. M.; KAMAL, S. \& JORDANA, J. On biometrical aspects of the cephalic anatomy of Xisqueta Sheep (Catalunya; Spain). Int. J. Morphol., 28(2):347-351, 2010.

SUMMARY: This study, based on a 48 Xisqueta skull samples, gives a statistical insight of the skull shape in this breed. Thirty eight measurements and eight indexes were recorded. The variance structure was done using a Principal Component Analysis (PCA). This was possible sequel to the application and permission of the covariance matrix. The mean length of the skulls was found to be $265.51 \pm 22.24 \mathrm{~mm}$, with the width and cephalic index to the magnitude of $117.2 \pm 6.89 \mathrm{~mm}$ and $44.69 \pm 4.29 \mathrm{~mm}$, respectively. The viscerocranium length was $143.07 \pm 9.74 \mathrm{~mm}$ thus indicating a similar portion with the neurocranium part of the skull (137.17 $\pm 6.25 \mathrm{~mm})$. The orbit was slightly almond shaped. Variability was generally high within parameters but parameter variation was less in regard to basal surface length parameters than the others. The results from Principal Component Analysis indicated that skull variance was concentrated on the first two components. The first principal component explained $99.21 \%$ of the generalized variance in skull parameters and gave special emphasis to viscerocranium. The second principal component may be called the neurocranial component. The first and the second principal components explained $99.77 \%$ of the observed variance. The third principal component was related with foramen magnum and orbital parameters.

KEY WORDS: Anatomy; Craniometry; Osteometry; Skull.

\section{INTRODUCTION}

In the studies on the morphological variability of domestic and wild mammals much emphasis is placed on changes in the skeletal structures. Morphometric analyses show the variability in the shape and proportions of the bones of the skull which are influenced by the effect of genetic and environmental factors.

Thus, craniometry has a prominent role in osteological investigations. The skull is frequently the major element of the skeleton indicating taxonomic affiliation, and giving information on changes in animals as a result of selection (Bruenner et al., 2002).

The regional anatomy of the head gathers its importance itself due the fact that comparative data are of value in osteoarchaeology. Craniometric studies of domesticated animals are commonly reported in the scientific literature (Grigson, 1974; Guintard \& Fouché, 2008). Compilation from known breeds can be used as a standard to which future work will refer but few papers investigate the intraracial variation of the skull, a study which could provide clues on the correlated evolution of cranial characters and on the role of selective pressures in producing morphological adaptations. Moreover, the study in a breed constitutes very interesting investigation material because one expects to obtain less variability.

The purpose of this study is to check the skull structure in the Xisqueta ovine breed and identify the craniometric traits that play a decisive role in variability.

The Xisqueta is an indigenous breed of pyrenean region in Spain reared uniquely for meat purposes. The Xisqueta sheep, which is known for longevity, is descendant of primitive sheep that arrived from Central Asia (Jordana \& Ribó, 1991). They are close to the ancestral model, and in fact, these breeds show little morphological differences among them. These populations are mainly located in highland areas such as the Iberian System (Ojalada sheep), the Penibetic System (Montesina sheep) and the Pyrenees (Xisqueta sheep)

* Dept. of Animal Anatomy. Animal Science \& Health. University of Lleida. Catalunya, España.

** Division of Veterinary Anatomy \& Histology, F. V. Sc. \& A. H., S. K. University of Agricultural Sciences \& Technology, R. S. Pura, Jammu, India.

**** Dept. de Ciència Animal i dels Aliments, Facultat dde Veterinària, Universitat Autònoma de Barcelona, Edifici V, o8193 Bellaterra, España. 
and they are commonly known as Serrana breeds. The original nucleus of the Xisqueta is situated in the $\mathrm{N}$ of the Pallars region but the breed expanded towards the high Catalan Pyrenees, central regions of Lleida and close areas of Huesca (Spain). However, the progressive decline of the breed, since the middle of the XXth century, has caused a gradual reduction of its geographical distribution range (Avellanet, 2002). As such no extensive anatomical study has been conducted on craniometrical aspects of the skull in this breed yet.

Moreover the complete morphological aspects of the skull related particularly to spanish breeds are scarce in the bibliographic notes, especially for ovines of the Xisqueta breed; therefore, the results of this research will contribute to the best knowledge of it anatomy and, in parallel, will offer elements for eventual comparative studies.

\section{MATERIAL AND METHOD}

In this present study a total number of 48 skulls of adult (at least M3 erupting) Xisqueta sheep were utilized. The size of individual analytical samples differed slightly from one parameter to another because the occasional skull was broken. The heads of these animals were obtained from an ossuary destined to feed naturally vultures and bearded vultures. All animals were females and with no apparent skeletal disorders. For all the individuals their breeder was unknown but origin farms were located in the same county.

Different craniometrical parameters were recorded following von Driesch (1976) with the help of callipers. The measurements are in millimeters to the nearest $0.5 \mathrm{~mm}$. Overall 38 skull measurements were included in the analysis as under. No measurement was taken on horncore because this breed is poled.

\section{Skull parameters (dorsal and basal surface).}

1. Total length of the skull: the distance between points: akrokranion and prosthion.

2. Condylobasal length: aboral border of occipital condylesprosthion.

3. Total length of the cranial basal: basion-prosthion.

4. Short skull length: basion-premolare.

6. Neurocranium length: basion-nasion.

8. Median frontal length: akrokranion-nasion.

9. Akrokranion-bregma.

10. Frontal length: bregma-nasion.

11. Upper neurocranium length: akrokranion-supraorbitale.

13. Akrokranion-infraorbitale of one side.

17. From the aboral border of one occipital condile to the infraorbitale of the same side.

26. Greatest mastoid breadth: otion-otion.
28. Greatest breadth at the bases of the paraoccipital processes.

31. Least breadth of parietal.

33. Greatest neurocranium breadth: neryon-euryon.

34. Greatest frontal breadth: ectorbitale-ectorbitale.

35. Least breadth between the orbits: entorbitale-entorbitale.

\section{Foramen magnum.}

27. Greatest breadth of the occipital condyles.

29. Greatest breadth of the foramen magnum.

30. Heigth of the foramen magnum: basion-opisthion.

\section{Dental parameters.}

18. Dental length: postdentale-prosthion.

19. Oral palatal length: palatinoorale-prosthion.

20. Lateral length of the premaxilla: nasointermaxillare-prosthion.

21 . Length of the cheektooth row.

22 . Length of the molar row.

23. Length of the premolar row.

39. Greatest palatal breadth.

\section{Orbital parameters.}

24. Greatest inner width of the orbit: ectorbitale-entorbitale.

25. Greatest inner height of the orbit.

\section{Facial and nasal parameters.}

5. Premolare-prosthion.

7. Upper length of the viscerocranium: nasion-prosthion.

12. Facial length: supraorbitale-prosthion.

14. Greatest length of the lacrimal: most lateral point of the lacrimal - the most oral point of the lacrimo-maxillary suture.

15. Greatest length of the nasals: nasion-rhinion.

16. EntP - short lateral facial length: entorbitale-prosthion.

36. Facial breadth: between facial tuberosities.

37. Greatest breadth across the nasals.

38. Greatest breadth across the premaxilla.

From these measurements height indexes were obtained as under.

A. Skull/cephalic index: greatest frontal breadth (34) / total length of the skull (1) x 100 .

B. Cranial index: greatest neurocranium breadth (33) / neurocranium length (6) x 100 .

C. Area of foramen magnum (according to Sarma, 2006): by using the formula $1 / 4 \mathrm{wh}$, where w=width (29) and $\mathrm{h}=$ heigth (30) of the foramen magnum.

D. Orbital index: greatest breadth of the foramen magnum (29) / heigth of the foramen magnum (30) x 100.

E. Orbital area (according to Sarma): Pab, where a and b are the halves of orbital inner width (24) and heigth (25), respectively.

F. Facial index: facial breadth (36) / facial length (12) x 100.

G. Frontal index: least breadth between the orbits (35) / frontal length $(10) \times 100$.

H. Nasal index: greatest breadth across the nasals (37) / greatest length of the nasals (15) x 100 .

Ethical approval was not required as all tissue was collected postmortem. 
Simple statistics data were obtained. Covariance is the preferred statistic when character measures are reasonably commensurable (Stevens, 1992). After the covariance matrix which was the primary data for the analysis was generated, it was inspected for adequate determinant factor, sampling adequacy (Kaiser-MeyerOlkin test) and sphericity (Bartett's test). The next method used in this study was Principal Components Analysis with 3 factors in which the covariance matrix was the primary data. The procedure for determining the number of dimensions was a parallel analysis with a number of random data matrices $=500$ (Horn, 1965). The rotation to achieve factor simplicity was Promax with a value of parameter $\mathrm{k}=4.0000$; the maximum number of iterations was 100. Statistical analyses were performed using the "Paleontological Statistics Software Package for Education and Data Analysis" (Hammer et al., 2001) and the FACTOR software (Lorenzo-Seva \& Ferrando, 2007).

\section{RESULTS AND DISCUSSION}

Results of the descriptive analysis are presented in Table I. CV expressed in \% are high contrasting those obtained by Agüera et al. (1988b) who obtained CV < 6 $\%$ using radiographic parameters in Manchega and Merina breeds. Higher CV tend to appear in dental parameters. $\mathrm{CV}<4 \%$ appeared in basal surface length parameters. The high variability shown could be a mere reflection of wide variation among actual breeder of the studied animals which was not known. It is also likely that the figures obtained might be lower than those reported for the same animals of known actual breeders. Lateral length of the premaxilla and length of the premolar row are the most parameters, being area of foramen magnum and nasal index the most variable indexes. The mean length of the skulls were found to be $265.51 \pm 22.24 \mathrm{~mm}$, with the width and cephalic index to the magnitude of $117.2 \pm 6.89 \mathrm{~mm}$ and $44.69 \pm 4.29 \mathrm{~mm}$, respectively. The Xisqueta skull is slightly minor than either Merino or Segureña as reported by Agüera et al. (1988a), which were $280.4 \pm 3.02$ and $272.8 \pm 3.07 \mathrm{~mm}$ respectively. The viscerocranium length $(143.07 \pm 9.74 \mathrm{~mm})$ indicated a similar portion with the neurocranium part of the skull $(137.17 \pm 6.25 \mathrm{~mm})$. The measurements showed also that the skull in Xisqueta sheep was elongated in shape as also reported in goats (Sarma). The frontal bone contributed to the half of the total length. The forehead is broad in relation to the breadth of the skull but not in relation to the total length of the skull. The orbit was slightly almond in shape (orbital index $=109.77 \pm 10.23$ ).
Table I. Results of the descriptive analysis (measures in $\mathrm{mm}$ ) obtained in the study of 48 skulls of adult Xisqueta sheep.

\begin{tabular}{|c|c|c|c|c|}
\hline Parameters & Mean & S.E. & $\mathrm{CV} \%$ & Range \\
\hline 1 & 265.51 & 22.24 & 8.38 & $236.7-335.1$ \\
\hline 2 & 242.07 & 8.20 & 3.39 & $228.3-261.0$ \\
\hline 3 & 223.14 & 8.69 & 3.90 & $205.8-243.0$ \\
\hline 4 & 155.89 & 6.08 & 3.90 & $147.4-174.6$ \\
\hline 5 & 67.85 & 4.66 & 6.87 & $59.4-79.0$ \\
\hline 6 & 137.17 & 6.25 & 4.55 & $126.6-150.0$ \\
\hline 7 & 143.07 & 9.74 & 6.81 & $121.8-162.0$ \\
\hline 8 & 134.10 & 5.33 & 3.97 & $122.4-146.4$ \\
\hline 9 & 50.41 & 4.58 & 9.09 & $30.0-58.0$ \\
\hline 10 & 95.97 & 6.42 & 6.69 & $80.9-121.1$ \\
\hline 11 & 100.26 & 4.51 & 4.50 & $92.6-114.0$ \\
\hline 12 & 189.22 & 8.24 & 4.36 & $169.5-202.7$ \\
\hline 13 & 195.68 & 15.45 & 7.90 & $166.5-228.5$ \\
\hline 14 & 51.19 & 4.02 & 7.85 & $39.7-58.0$ \\
\hline 15 & 92.12 & 8.71 & 9.45 & $68.8-107.3$ \\
\hline 16 & 154.45 & 7.23 & 4.68 & 138.4-164.6 \\
\hline 17 & 170.06 & 7.24 & 4.26 & 152.2-191.6 \\
\hline 18 & 131.37 & 6.31 & 4.80 & 117.0-144.1 \\
\hline 19 & 104.97 & 5.56 & 5.30 & $95.6-119.0$ \\
\hline 20 & 83.98 & 9.30 & 11.07 & $67.0-108.8$ \\
\hline 21 & 70.80 & 5.19 & 7.34 & $60.5-83.0$ \\
\hline 22 & 47.38 & 3.97 & 8.38 & $30.3-54.8$ \\
\hline 23 & 25.39 & 4.01 & 15.79 & $19.6-39.2$ \\
\hline 24 & 39.07 & 1.75 & 4.49 & 35.843 .6 \\
\hline 25 & 36.93 & 2.32 & 6.27 & $25.8-42.0$ \\
\hline 26 & 112.80 & 5.74 & 5.09 & $99.7-130.7$ \\
\hline 27 & 49.50 & 2.97 & 6.00 & $42.2-57.5$ \\
\hline 28 & 68.36 & 4.36 & 6.38 & $62.0-79.5$ \\
\hline 29 & 20.48 & 1.42 & 6.95 & $17.8-24.4$ \\
\hline 30 & 18.75 & 1.53 & 8.14 & $13.3-22.2$ \\
\hline 31 & 46.68 & 4.06 & 8.70 & $39.6-56.0$ \\
\hline 33 & 67.07 & 2.60 & 3.88 & $62.0-74.6$ \\
\hline 34 & 117.20 & 6.89 & 5.88 & $101.5-131.9$ \\
\hline 35 & 88.70 & 6.26 & 7.06 & $74.0-103.9$ \\
\hline 36 & 77.44 & 5.24 & 6.76 & $69.0-92.0$ \\
\hline 37 & 36.80 & 3.57 & 9.70 & $31.1-47.3$ \\
\hline 38 & 45.66 & 3.60 & 7.89 & $38.6-53.8$ \\
\hline 39 & 67.63 & 4.12 & 6.10 & $59.7-80.2$ \\
\hline A & 44.69 & 4.29 & 9.59 & $35.8-53.3$ \\
\hline B & 48.33 & 3.04 & 6.29 & $38.0-53.3$ \\
\hline $\mathrm{C}$ & 96.17 & 11.67 & 12.13 & $61.8-123.4$ \\
\hline $\mathrm{D}$ & 109.77 & 10.23 & 9.32 & $92.5-139.8$ \\
\hline $\mathrm{E}$ & 1133.84 & 94.24 & 8.31 & 829.0-1391.9 \\
\hline $\mathrm{F}$ & 41.48 & 2.72 & 6.56 & $38.2-48.7$ \\
\hline $\mathrm{G}$ & 92.64 & 6.60 & 7.12 & $79.5-110.0$ \\
\hline $\mathrm{H}$ & 40.11 & 4.54 & 11.31 & $32.8-52.3$ \\
\hline
\end{tabular}

Kaiser-Meyer-Olkin (KMO) measure of sampling adequacy revealing the proportion of the variance in the skull measurements caused by underlying factor $(\mathrm{KMO}=1)$ and the Barlett's test of sphericity (949.9, $\mathrm{df}=1035)$, communalities in the unrotated loading matrix which is the explained variance together with the determinant (0.005), obtained from the 


\begin{tabular}{ccccc}
$\begin{array}{c}\text { Principal } \\
\text { Component }\end{array}$ & Eigenvalue & $\begin{array}{c}\text { Proportion } \\
\text { of variance }\end{array}$ & $\begin{array}{c}\text { Cumulative proportion of } \\
\text { variance }\end{array}$ & \\
\cline { 1 - 4 } 1 & 162.420 .641 .140 & 0.99213 & 0.99213 & Table II. Explained variance \\
2 & 912.288 .424 & 0.00557 & 0.99770 & based on eigenvalues. \\
3 & 176.196 .837 & 0.00108 & 0.99878 & \\
\hline
\end{tabular}

Table III. Rotated loading matrix (raw varimax clever rotation). Loadings lower than absolute 0.500 omitted.

covariance matrix permitted all skull measurements into reasonable factor analysis-PCA. The PCA analysis revealed 22 components with eigenvalues being bigger than 1.0. The first 3 factors jointly explained $99.87 \%$ of the total variability formed by the 46 biometrical traits (Table II). Then each parameter was given a load (raw varimax clever rotation); the loads appear in Table III. The PC1 was especially linked with traits reflecting the facial and nasal area. The PC1 may be called the anterocranial component because it gave high emphasis to the viscerocranium lengths (124.967-141.152). It had basically positive loadings on the above parameters of the skull and it would indicate a proportional increasing in the dimensions in relation to one another. The distance from nasion to prosthion exhibited the highest discriminating power (141.152). This feature would indicate variability in the capacity to wildly forage, which in turn is connected with the adaptation of the breed to eat between bushes. The PC 2 defined the total and the akrokranion-infraorbitale lengths (530.851965.483). It may be called the neurocranial component. The PC1 and PC2 explained $99.77 \%$ of the observed variance. PC3 was connected with foramen magnum and orbital parameters.

The skulls of all mammals share certain developmental patterns, like ontogenetic facial elongation, that are likely to constrain their variance. These structures have a greater number of independent PCs.

As stated earlier, there is no previous information on complete cephalic anatomy in Xisqueta skulls, nor in any other sheep breed in Spain with which comparisons could be made. We therefore believe that the data presented above will form a good baseline for further work especially comparability are desirable traits when efforts are geared up towards comparison between ancient and non extinguished ovine breeds based on skull samples.

ACKNOWLEDGEMENTS. We thank Pepe Guillén for kindly providing the material used in this study.

\begin{tabular}{|c|c|c|c|}
\hline Parameter & C1 & C2 & C3 \\
\hline 1 & 17.023 & 965.483 & 867.596 \\
\hline 2 & 28.761 & 82.907 & 112.517 \\
\hline 3 & 45.601 & 114.483 & 148.492 \\
\hline 4 & 35.446 & 59.952 & 86.433 \\
\hline 5 & 29.648 & 43.181 & 82.275 \\
\hline 6 & -21.082 & 56.906 & 12.173 \\
\hline 7 & 141.152 & 12.891 & 149.347 \\
\hline 8 & -52.918 & 120.092 & 48.704 \\
\hline 9 & -2.203 & -64.269 & -59.632 \\
\hline 10 & -58.203 & 155.977 & 66.742 \\
\hline 11 & -18.126 & 86.411 & 53.514 \\
\hline 12 & 96.619 & 75.929 & 141.921 \\
\hline 13 & -96.250 & 530.851 & 430.112 \\
\hline 14 & 0.887 & 3.060 & -1.439 \\
\hline 15 & 124.967 & -9.969 & 120.562 \\
\hline 16 & 76.502 & -6.074 & 60.952 \\
\hline 17 & 19.726 & 103.053 & 98.752 \\
\hline 18 & 79.232 & 47.977 & 125.145 \\
\hline 19 & 51.333 & 51.683 & 103.323 \\
\hline 20 & 3.534 & -98.974 & -92.672 \\
\hline 21 & 8.330 & -16.923 & -20.463 \\
\hline 22 & -5.852 & 31.882 & 10.831 \\
\hline 23 & 11.598 & -63.947 & -54.902 \\
\hline 24 & 1.085 & 37.138 & 23.508 \\
\hline 25 & -0.972 & 2.775 & -24.650 \\
\hline 26 & 20.507 & 90.539 & 85.597 \\
\hline 27 & 3.373 & 28.645 & 21.731 \\
\hline 28 & & 81.966 & 55.355 \\
\hline 29 & 1.275 & -13.614 & -12.796 \\
\hline 30 & -5.169 & -38.849 & -41.107 \\
\hline 31 & -10.730 & 63.661 & 37.729 \\
\hline 33 & & 42.419 & 34.263 \\
\hline 34 & -5.303 & 62.274 & 39.452 \\
\hline 35 & 16.945 & 59.090 & 50.045 \\
\hline 36 & & 108.238 & 85.529 \\
\hline 37 & 6.492 & 11.816 & 4.701 \\
\hline 38 & -4.749 & 64.062 & 52.157 \\
\hline 39 & -2.596 & 82.654 & 59.298 \\
\hline A & -6.796 & -127.207 & -122.363 \\
\hline B & 12.125 & 23.406 & 36.309 \\
\hline $\mathrm{C}$ & -18.963 & -261.060 & -268.929 \\
\hline $\mathrm{D}$ & 40.230 & 181.450 & 197.391 \\
\hline $\mathrm{E}$ & -2.853 & 1.193 & -74.444 \\
\hline $\mathrm{F}$ & -20.113 & 43.466 & 13.016 \\
\hline $\mathrm{G}$ & 75.396 & -79.803 & -3.141 \\
\hline $\mathrm{H}$ & -52.033 & 12.702 & -49.808 \\
\hline
\end{tabular}


PARÉS I CASANOVA, P. M.; KAMAL, S. \& JORDANA, J. Aspectos biométricos de la anatomía cefálica de la Oveja Xisqueta (Cataluña, España). Int. J. Morphol., 28(2):347-350, 2010.

RESUMEN: Este estudio, basado en una muestra de 48 cráneos de Xisqueta, da una visión estadística de la biometría del cráneo de esta raza. Treinta y ocho mediciones y ocho índices fueron tomados. La longitud media de los cráneos se encontraron entre $265,51 \pm 22,24 \mathrm{~mm}$ con el ancho e índice cefálico con la magnitud de 117,2 $\pm 6,89 \mathrm{~mm}$ y 44,69 $\pm 4,29 \mathrm{~mm}$ respectivamente. La longitud del viscerocráneo fue $143,07 \pm 9,74 \mathrm{~mm}$, lo que indica una porción similar con la parte del neurocráneo $(137,17 \pm 6,25 \mathrm{~mm})$. La órbita tuvo una forma ligeramente de almendra. La variabilidad fue generalmente alta dentro de los parámetros, pero fueron menores en la longitud de la superficie basal. La estructura de varianza se realizó utilizando un Análisis de Componentes Principales (ACP). Esto fue posible gracias a la aplicación y la permisividad de la matriz de covarianza. La solución del ACP indica que la varianza del cráneo se concentró en los dos primeros componentes. El primer componente principal explicó el 99,21\% de la varianza generalizada en los parámetros de cráneo y prestó especial atención al viscerocráneo. El segundo componente principal se puede llamar el componente neurocráneo. El primer y el segundo componente principal explicaron $99,77 \%$ de la varianza observada. El tercer componente principal estaba relacionado con el foramen magno y los parámetros orbitales.

PALABRAS CLAVE: Anatomía; Craneometría; Osteometría; Cráneo.

\section{REFERENCES}

Agüera, S.; Rodríguez, V.; Miró, F. \& Vivo, R. Parámetros cefálicos radiográficos de la oveja Merina y Segureña y su aplicación racial. Arch. Zoot., 37(138):115-25, 1988a.

Agüera, S.; Castejón, F. J.; Diz; A.; Miró, F. \& López Rivero, J. L. Diferenciación racial de la oveja Manchega y Merina mediante valoración de parámetros radiográficos Cefálicos. Arch. Zoot., 37(139):205-67, 1988 b.

Avellanet, R. La raza ovina Xisqueta: Estudio biométrico y caracterización estructural de las explotaciones. Tesina de Investigación. Universidad Autónoma de Barcelona, Barcelona, 2002.

Bruenner, H.; Lugon-Moulin, N.; Balloux, F.; Fumagalli, L. \& Hausser, J. A taxonomical re-evaluation of the Valais chromosome race of the common shrew Sorex araneus (Insectivora: Soricidae). Acta Theriol., 47:245-75, 2002.

Driesch, A. V. D. A Guide to the Measurement of animal bones from archaeological sites. Peabody Museum Bull., 1:1137, 1976.

Grigson, C. The craniology and relationship of four species of Bos. 1, Basic Craniology: Bos taurus L. and its Absolute Size. J. Archaeological Sci., 1:353-79, 1974.

Guintard, C. \& Fouché, S. Etude ostéometrique de têtes osseuses de moutons (Ovis aries, L.). Revue Méd. Vét., 159(12):603-17, 2008.
Hammer, Ø.; Harper, D. A. T. \& Ryan, P. D. PAST: Paleontological statistics software package for education and data analysis. Palaeontologia Electronica, 1(4):1-9, 2001.

Horn, J. L. A rationale and test for the number of factors in factor analysis. Psychometrika, 30:179-85, 1965.

Jordana, J. \& Ribó O. Relaciones filogenéticas entre razas ovinas españolas obtenidas a partir del estudio de caracteres morfológicos. Investigación Agraria: Producción y Sanidad Animales, 6(3):225-37, 1991.

Lorenzo-Seva, U. \& Ferrando, P. J. Unrestricted Factor Analysis. Release v. 7.00, 2007.

Sarma, K. Morphological and craniometrical studies on the skull of Kagani goat (Capra hircus) of Jammu Region. Int. J. Morphol., 24(3):449-55, 2006.

Stevens, J. Applied multivariate statistics for the social sciences. Hilldae, Lawrence Erlbaum Associates, 1992.

Correspondence to:

Parés, I.

Dept. of Animal Anatomy. Animal Science \& Health.

University of Lleida. Catalunya

SPAIN

Email: peremiquelp@prodan.udl.cat

Received: 26-08-2009 Accepted: 22-02-2010 
